\title{
Małgorzata Mielcarek
}

Uniwersytet im. Adama Mickiewicza w Poznaniu

\section{Nowe media - nowe dziennikarstwo?}

\section{WPROWADZENIE}

$\mathrm{D}$ ZIENNIKARZE, jako wyodrębniona grupa społeczna ${ }^{1}$ w Polsce, odgrywają ważną rolę w kształtowaniu zachowań obywatelskich czy kreowaniu postaw politycznych. Wynika to nie tylko z liczebności tej grupy zawodowej, ale przede wszystkim z nieustannej obecności mediów w codziennym życiu milionów odbiorców. Podstawowe zadania dziennikarzy, mimo rozwoju nowych form komunikacji masowej i społecznej, w zasadzie wydają się pozostawać takie same. Niemniej ulegały one i nadal ulegają przekształceniom, podobnie jak sam status dziennikarza czy forma i funkcje materiału prasowego.

Pierwsze internetowe serwisy informacyjne, w większości funkcjonowały jako wirtualne odpowiedniki istniejących wcześniej gazet i czasopism. Sytuacja zaczęła się zmieniać wraz ze wzrostem znaczenia wirtualnej informacji ${ }^{2}$, co niemal natychmiast dostrzegło wielu badaczy. W latach 90. ubiegłego stulecia Roger F. Fiedler sformułował hipotezę mediamorphosis, w myśl której komunikacja medialna przeobraża się m.in. za sprawą nowych technologii ${ }^{3}$. Wkrótce pojawiła się również hipoteza journamorphosis ${ }^{4}$, zgodnie z którą nieuchronnym następstwem zmian technologicznych i medialnych jest metamorfoza samego dziennikarstwa.

Słowami kluczami, które mają oddawać specyfikę nowych mediów, są „hipertekst”, „symulacja”, „konwergencja”, „blogosfera” i „Sieć 2.0”. Niemniej chcąc uchwycić logikę nowomedialną, należy

${ }^{1} \mathrm{~W}$ psychologii społecznej i socjologii do grupy społecznej zaliczamy zbiór co najmniej trzech osób, które działają na zasadzie odrębności od reszty społeczeństwa, charakteryzujące się wspólnym systemem norm, wartości i celów.

${ }^{2}$ L. Olszański, Dziennikarstwo internetowe, Warszawa 2006, s. 78.

3 Patrz: R. F. Fiedler, Mediamorphosis: Understanding New Media, Thousand Oaks-London 1997.

${ }^{4}$ Uważa się, że autorem określenia journamorfosis jest prof. Mark Butzow z Uniwersytetu Zachodniego Illinois, który na swoim blogu www.journamormphosis.blog-spot.com omawia zmiany w systemie pracy dziennikarza pod wpływem nowych technologii 
niekiedy operować tymi terminami jednocześnie, co może być nader trudne, bowiem ich zakresy zachodzą na siebie, zacierając granice między obszarami ich stosowania. Zjawiska, ku którym odsyła rozpatrywana terminologia, bez względu na brak jej precyzji, zasadniczo wpływają na styl pracy dziennikarzy oraz generalnie - na etos tego zawodu, ukształtowany w okresie „panteizmu-druku”. W efekcie zmian techniczno-warsztatowych przeformowaniu ulegają także gatunki wypowiedzi dziennikarskich, i to niezależnie od tego czy autorami tych wypowiedzi są dziennikarze zawodowi czy też „obywatelscy”.

Chcąc scharakteryzować funkcje dziennikarstwa oraz sposób pracy dziennikarzy w nowych mediach, należy przedstawić ich pozycję w polskim systemie prawnym. Rozwój nowych technik przekazu sprawia, że powraca i nabiera znaczenia wielokrotnie zadawane pytanie, kto tak naprawdę jest dziennikarzem. Czy staje się nim każdy, kto napisze krótką notkę informacyjną na portalu internetowym, osoba posiadająca dziennikarskie wykształcenie czy zatrudniona w profesjonalnej redakcji?

Polska ustawa Prawo prasowe uchwalona w 1984 r., może być uznana za nieadekwatną do obecnej sytuacji na rynku medialnym. Ustawodawca uważa bowiem, że dziennikarzem jest zarówno ta osoba, która pozostaje w stosunku pracy z redakcją, jak i ta, która zajmuje się taką działalnością na rzecz i z upoważnienia redakcji ${ }^{6}$. Zatem ktoś, kto przygotowuje materiały prasowe dla obywatelskiego portalu internetowego, który nie posiada statusu w pełni wykształconej redakcji, nie ma praw dziennikarza. Rzadko kiedy też osoba zajmująca się przygotowywaniem materiałów prasowych umieszczanych na „nieprofesjonalnym” portalu informacyjnym pobiera z tego tytułu wynagrodzenie czy podpisuje umowę z redakcją. Nie może zatem ubiegać się o informacje od instytucji państwowych, których są one zobligowane udzielać pełnoprawnemu dziennikarzowi, ale też nie jest ona uprawniona do korzystania z tajemnicy dziennikarskiej.

Do Internetu dziennikarzy przyciągnęła szybkość transmisji informacji, a także względna łatwość jej aktualizacji bez konieczności pisania nowego tekstu. Jednocześnie można dokonywać szybkich kompilacji tekstów przychodzących z nowych źródeł, na ogół anonimowych, co nie jest bez znaczenia. $Z$ drugiej jednak strony wielość źródeł i ich z pozoru wygodna anonimowość budzą nieufność co do

${ }^{5}$ Z. Bauer, Dziennikarstwo wobec Nowych Mediów, Kraków 2009, s. 277.

${ }^{6}$ J. Sobczak, Prawo prasowe. Komentarz, Warszawa 2008, s. 328. 
autentyczności przekazywanych informacji. W Stanach Zjednoczonych brak zaufania do mediów elektronicznych wzmaga się m.in. ze względu na fakt silnego zakorzenienia się w środowisku dziennikarskim i w kręgach ludzi zajmujących się mediami doktryny odpowiedzialności społecznej. Zgodnie z tą doktryną, jedynie profesjonalni dziennikarze mogą ponosić odpowiedzialność za prawdziwość, rzetelność i obiektywizm przekazywanych wiadomości. Jest to, rzecz jasna, nie tyle doktryna determinująca metody dziennikarskiej pracy, ile stały punkt odniesienia w ocenie wizerunku i habitusu mediów?

Społeczeństwo posiada dużo większą kontrolę nad dziennikarzem nowych mediów niż mediów tradycyjnych. Rezultaty pracy tego pierwszego są nieustannie poddawane krytyce, publiczność nigdy wcześniej niemal natychmiast nie zapoznawała się i nie oceniała efektów pracy dziennikarskiej. Ma to ogromny wpływ na jej styl. Dziennikarz nowych mediów nie tylko musi być bardziej odporny na krytyczne uwagi, ale często jest dalece bardziej zaangażowany w przygotowywanie newsa czy artykułu, gdyż nie może sobie pozwolić na potknięcie. Każda pomyłka zostanie wychwycona, a dziennikarz wyszydzony. Jeszcze nigdy tempo przygotowywania informacji nie było tak szybkie, a deadline’y redakcyjne tak krótkie ${ }^{8}$ - wyznaczane przez każde warte wzmianki wydarzenie. Te i wcześniej wspomniane już zmiany wynikające z różnic technologicznych i mentalnych wpłynęły na wykształcenie się dwóch typów dziennikarstwa - tradycyjnego, obecnego w telewizji, prasie drukowanej czy w radiu oraz tego poniekąd wygenerowanego przez nowe media.

\section{FUNKCJE DZIENNIKARSTWA TRADYCYJNEGO}

Tradycyjne DZIENNIKARSTwo, z jego funkcjami, zadaniami, technikami komunikowania i gatunkami, kształtowało się od początku istnienia prasy. Podstawą jej kreowania była potrzeba uzyskiwania informacji. Dostarczanie ich stało się bazą dla tworzenia społeczeństwa informacyjnego. Jednocześnie informacje pomagają w funkcjonowaniu czytelników w życiu codziennym i ułatwiają podejmowanie decyzji, przed którymi stoją uczestnicy rynku i obywatele ${ }^{9}$. Wpływ na polityczne wybory wywierają zarówno opiniotwórcze artykuły, jak również pozycjonowanie odpowiednich newsów, wybór osób, z którymi się przeprowa-

\footnotetext{
${ }^{7}$ Z. Bauer, Dziennikarstwo..., op. cit., Kraków 2009, s. 228.

${ }^{8}$ L. Olszański, Dziennikarstwo..., op. cit., Warszawa 2006, s. 5.

${ }^{9}$ M. Chyliński, S. Russ-Mohl, Dziennikarstwo, Warszawa 2008, s. 19.
} 
dza wywiady, a także proste przedstawienie wyników sondaży i badań opinii publicznej. Niejednokrotnie ich prezentacja wyraźnie wpływała na późniejsze wybory polityczne obywateli, tak jak w 2005 r., przed wyborami prezydenckimi w Polsce ${ }^{10}$.

Polityka nie jest jedyną sferą oddziaływania dziennikarstwa tradycyjnego. Jedną z „miękkich” funkcji dziennikarstwa jest tworzenie międzykulturowych mostów poprzez zatrudnianie obcokrajowców w mediach ogólnopolskich czy w programach rozrywkowych. Integrację różnych kultur, ale także rozmaitych stylów życia od lat promuje się w innych krajach, a od niedawna także w Polsce. Pionierami były stacje radiowe, które angażowały egzotycznych i kaleczących język polski didżejów. Jednym z pierwszych był Brian Scott w RMF FM ${ }^{11}$. Dziś takim przykładem jest program Pascala Brodnickiego, francuskiego kucharza prowadzącego jeden z najpopularniejszych programów kulinarnych.

Interesującym zjawiskiem jest konwergencja tradycyjnych i nowych mediów, np. gdy dodatek edukacyjny w postaci płyty CD czy DVD dołącza się do gazety papierowej. W ten sposób realizuje się kolejną z funkcji tradycyjnego dziennikarstwa - nauczanie. Nierzadko zdarza się, że media wypełniają luki w edukacji, których nie jest w stanie wypełnić szkoła czy uniwersytet.

Tradycyjny dziennikarz wraz ze swoim medium starał się także jak najwcześniej ostrzegać jednostki i społeczeństwo. Artykulacja pewnych zjawisk i problemów, podawanie ich do publicznej świadomości niejednokrotnie pomagały i pomagają bardziej niż instytucje powołane do tego przez państwo. Można mnożyć przykłady tradycyjnych reportaży czy programów interwencyjnych. „Telekurier” Telewizji Publicznej czy „Prosto z Polski” emitowane w TVN - nierzadko niwelują opieszałość służb odpowiedzialnych za opiekę socjalną czy wpływają na zmiany przepisów. Media sprawują zatem swoistą opiekę nad obywatelem, pełniąc zarazem rolę jego rzecznika i obrońcy.

Kolejna z funkcji tradycyjnego dziennikarstwa sięga XIX w., kiedy tzw. prasa groszowa (Penny Press) zaczęła docierać do masowego odbiorcy $^{12}$. Mowa o rozrywce, która dziś zdaje się wypierać dzienni-

${ }^{10}$ Wyniki sondażu przeprowadzonego przez OBOP sugerowały zwycięstwo w wyborach Donalda Tuska. Sądzi się, że miało to duży wpływ na mobilizację elektoratu jego głównego rywala - Lecha Kaczyńskiego i demobilizację elektoratu D. Tuska, co ostatecznie doprowadziło do wygranej L. Kaczyńskiego.

${ }^{11}$ Ibidem, s. 25.

${ }^{12}$ Ibidem, s. 23. 
karstwo informacyjne oraz publicystyczne. Proces ten można zaobserwować przy zmianie sezonowych ramówek telewizji zarówno prywatnej, jak i publicznej, gdzie z roku na rok ubywa miejsca na programy edukacyjne. Te są wypierane do osobnych kanałów tematycznych czy informacyjnych, takich jak TVP Historia, TVN24, lub TVP info. Kanał pierwotny zostaje wypełniony programami typowo rozrywkowymi, niewymagającymi wiedzy, oczytania ani zaangażowania intelektualnego. Trudno jednak rozrywkę uznać za jedną z podstawowych funkcji dziennikarstwa. Bardziej niż pierwotnym zadaniem, jest ona efektem ubocznym rozwoju technik informacyjnych.

Ostatnią, choć nie najmniej istotną funkcją dziennikarza, jest krytyka i kontrola otaczającej rzeczywistości ${ }^{13}$. Prasę nazywa się czwartą władzą nie bez przyczyny. Jak zauważył już Joseph Pulitzer: „Strach przed prasą udaremnił więcej przestępstw, korupcji i niemoralności niż prawo"14. Zaufanie do dziennikarzy w Polsce z roku na rok wzrasta. Wystarczy porównać zestawienia krajów ze względu na kryterium wolności prasy sporządzane przez organizację Reporterzy Bez Granic „Press Freedom Index”. W 2006 r. Polska zajęła 58 miejsce wśród 168 krajów. Rok później awansowała o 2 miejsca, by w 2008 r. uplasować się na 47 pozycji. Dziś zajmuje 37 miejsce ${ }^{15}$. To jeszcze nie powód do dumy, ale tak szybki awans w rankingu może napawać optymizmem.

\section{FunkcJe NOWEgo DZienNiKarstwa}

DZIENNIKARSTWO W NOWYCH MEDIACH pełni funkcje będące pochodnymi funkcji mediów tradycyjnych, a także miesza ze sobą zadania wcześniej wykonywane przez dziennikarzy i prezenterów. Przykładem takiego zjawiska jest infotainment ${ }^{16}$, co stanowi połączenie podstawowej funkcji dziennikarstwa, czyli informowania, z rozrywką. Sama informacja przestała być wystarczająca. Musi być przedstawiona w atrakcyjny, ale niezbyt skomplikowany sposób. Powinna być zaprezentowana prostym językiem i być w miarę możliwości krótka, poruszać jedynie najistotniejsze dla sprawy kwestie.

Dzisiejsze dziennikarstwo jest bliżej odbiorcy niż kiedykolwiek. Dzięki nieustannemu kontaktowi z obywatelem za pomocą komunika-

${ }^{13}$ Ibidem, s. 20.

${ }^{14}$ J. Rowe, Broadcoast news writing for professionals, Oak Park 2005, s. 14.

${ }^{15}$ Reporters without borders for press freedom, http://en.rsf.org/safety-of-journalists.html, 17.10.2010 r.

${ }^{16}$ Internetowe gatunki dziennikarskie, red. K. Wolny-Zmorzyński, W. Furman, Warszawa 2010, s. 75 . 
torów, komentarzy umieszczanych bezpośrednio obok materiału prasowego, dziennikarz zdaje sobie sprawę, co budzi największe zainteresowanie. Dlatego też wśród materiałów dziennikarskich znajdujących się w Internecie najwięcej jest tych społecznych, zaś mniej jest polityki. Świadczą o tym rozbudowane na najpopularniejszych portalach internetowych (Onet.pl, wp.pl, Interia.pl) działy lifestyle'owe, kulturalne czy poświęcone problematyce społecznej oraz zepchnięta na margines publicystyka.

Sama profesja dziennikarska również przestaje być zamknięta, dlatego zmienia się zestaw dziennikarskich kompetencji. Dziennikarz przygotowujący materiał do sieci często zatraca kreatywność i inwencję. Wystarczy porównać tytuły artykułów na kilku największych portalach informacyjnych. Pierwszych kilka nagłówków niemalże się pokrywa $^{17}$. Zdaje się, że artykuły, które znajdujemy w sieci, rzadko kiedy są efektem twórczej pracy, częściej zaś są kolażem kilku innych artykułów.

Internet jest miejscem, gdzie dużo wyraźniej niż w prasie tradycyjnej oddziela się komentarz od informacji. Na portalach informacyjnych znajduje się miejsce jedynie dla artykułów o charakterze informacyjnym. Opinie są zamieszczane na blogach czy prywatnych stronach dziennikarzy. Trudno określić dokładną liczbę blogów dziennikarskich, ale jeśli przyjąć, że każda wersja elektroniczna gazety drukowanej ma zakładkę „blog”, to może istnieć nawet kilkaset polskich blogów dziennikarskich. Poza tym można wyróżnić co najmniej dwa rodzaje dziennikarstwa blogowego - dziennikarzy piszących zarówno w sieci, jak i w mediach drukowanych tradycyjnych oraz dziennikarzy sieciowych prowadzących swoje blogi tylko w Internecie ${ }^{18}$. Oczywiście w polskiej blogosferze istnieje spora grupa bloggerów, którzy nie chcą ujawniać swojej tożsamości (przykład Kataryny - kataryna.blox.pl ${ }^{19}$ ), gdyż anonimowość zapewnia im niezależność i w konsekwencji wiary-

${ }_{17}$ Porównanie przeprowadzone 17 października 2010 r. O godz. 20:00 - główna wiadomość w dziale informacyjnym na Onet.pl: Zarzut zabójstwa dla Grzegorza W. Do zbrodni doszło $w$ domu, pierwsza wiadomość na wp.pl: Syn zabił ojca, byłego wiceministra - do zbrodni doszło $w$ domu, druga informacja na Interia.pl: Byty wiceminister nie żyje, zarzuty dla syna.

${ }^{18}$ M. Kawka, Blog jako gatunek dziennikarski [w:] Internetowe..., op. cit., s. 65.

${ }^{19}$ Kataryna jest jedną z najbardziej znanych komentatorek blogowych w Polsce. Na swoim blogu kataryna.blox.pl od 2002 r. na bieżąco komentuje wydarzenia ze świata polityki. Aktywnie uczestniczyła w debatach wśród dziennikarzy, np. biorąc udział w rozmowie w studiu telewizyjnym tvn24 za pośrednictwem komunikatorów internetowych. 
godność. Oddziałują oni w znaczny sposób na bieg wydarzeń społecznych czy politycznych, ich komentarze często mają podobną jakość jak opinie tzw. „pełnoprawnych” dziennikarzy, trudno jednak zaliczyć ich do tego grona.

Dziennikarstwo internetowe z czasem staje się bliższe dziennikarstwu tabloidowemu, nastawionemu na szokowanie. Dziennikarze coraz częściej ulegając determinacji, aby zdobyć newsa, skupiają się na sensacji. Presja czasu i możliwość nieustannego dostępu do sieci wymuszają na nadawcy, aby informował o wydarzeniach, które dopiero co miały miejsce. Dziennikarze, wyposażeni w mobilne komputery czy iphony mogą zdawać relacje z wydarzeń, których właśnie są świadkami. W ten sposób wykształca się przewaga nad tradycyjnymi mediami, używającymi wozów transmisyjnych, co wiąże się z wysokimi kosztami, na które nie każdą redakcję stać. Nowe dziennikarstwo znacznie częściej niż dziennikarstwo tradycyjne polega zatem na sprawozdawaniu „na żywo”. Dzięki nowym technologiom rozwijają się choćby internetowe relacje sportowe, kiedy to dziennikarz, będący świadkiem wydarzenia, na bieżąco może je opisywać. Przykładem są relacje na popularnych portalach - Onet.pl i Interia.pl, gdzie minuta po minucie są podawane pozycje piłkarzy i opisywana jest sytuacja na boisku. Coraz częstszym zjawiskiem staje się współpraca mediów tradycyjnych z dziennikarzami obywatelskimi, którzy pełnią rolę wszechwidzącego „oka medialnego”. Tak już od kilku lat pracuje portal tvn24. pl wraz z utworzonym na jego podobieństwo kontakt24.tvn.pl, gdzie znajdują się filmy, zdjęcia i informacje przesyłane przez użytkowników sieci.

\section{INFORMACJA W MEDIACH TRADYCYJNYCH I NOWYCH}

FunkcJE, jakie pełnią dziennikarze w zależności od rodzaju medium, którym się posługują, nieodłącznie oddziałują na sposób informowania, jak również na cechy wytwarzanej przez nich informacji. Ta przez lata kształtowania się telewizji, później zaś nowych mediów, ewaluowała od prostego komunikatu do rozbudowanego horyzontalnie tworu. Informacja tradycyjna posiadała strukturę piramidalną - część zasadnicza tekstu stanowiła podstawę, wyżej znajdował się lid, czyli początek tekstu, zaś na szczycie plasował się tytuł ${ }^{20}$. Co więcej, infor-

${ }^{20}$ L. Zakrzewska, Informacja, [w:] Dziennikarstwo od kuchni, red. A. Niczyperowicz, Poznań 2001, s. 18. 
macja była przedstawiana albo za pomocą tekstu, albo dźwięku, albo wideo.

W prasie tradycyjnej, jak radio czy telewizja, informacja była kontrolowana przez członków zespołów redakcyjnych, którym dostarczały ją agencje prasowe ${ }^{21}$. Dziennikarz stawał się członkiem elitarnej grupy, która w pewnym sensie dzierżyła władzę decydując o tym, które informacje staną się jawne, a które pozostaną w ukryciu. Sprawiało to, że określone grupy dbały o dobre kontakty z mediami, które mogły się hojnie odwdzięczyć przemilczaniem niekorzystnych, tudzież nagłaśnianiem korzystnych faktów.

Charakterystyczną cechą dla tradycyjnych mediów była znikoma presja czasu. Pojawiające się sporadycznie wiadomości dawały szansę na dopracowanie poszczególnych newsów, zaś większe formy dziennikarskie przygotowywano w ciągu dłuższych okresów czasu. Duży zastęp dziennikarzy zasilających redakcje dawał komfort podziału na role. W konkretnym materiale dziennikarz miał szansę wyjaśnić przyczyny danego wydarzenia, następnie zaś mógł stawiać hipotezy odnośnie następstw i skutków.

Nowe media poszukują innej informacji niż media tradycyjne, odmiennie informację też opracowują i upowszechniają. Natura informacji jako produktu podlega nieustannym zmianom. Przestaje być ekskluzywna ze względu na możliwość researchu 24 godziny na dobę. Dostęp do różnorakich baz danych możliwy jest niemal dla każdego za niewielką opłatą lub bez żadnych należności. W konsekwencji wzrasta też możliwość manipulowania informacją, co może prowadzić do negatywnego zjawiska dezinformacji ${ }^{22}$ - informacja niejako wszystkim jej użytkownikom zaczyna wymykać się spod kontroli. Wcześniej dysponowały nią wąskie grupy redaktorskie, teraz zaś o jej losie decydują osoby wcześniej niezaangażowane w proces tworzenia materiałów dziennikarskich. Z drugiej jednak strony ekspansja alternatywnych, niezależnych źródeł informacji, w połączeniu z rozpowszechnieniem ułatwiających dystrybucję wiadomości kanałów RSS spowodowały ogromny wzrost liczby dostępnych i niepozbawionych wartości źródeł. Często są one niezwiązane ze znanymi markami dziennikarskich potentatów ${ }^{23}$, co niekiedy zwiększa ich wiarygodność.

${ }^{21}$ M. Chyliński, S. Russ-Mohl, Dziennikarstwo, op. cit., s. 22.

${ }^{22}$ L. Olszański, Dziennikarstwo..., op. cit., s. 202.

${ }^{23} \mathrm{R}$. Good, The birth of the NewsMaster: The network starts to organise Itself, http://www.masternewmedia.org/2004/02/19/the_birth_of_the_newsmaster.htm, 17.10.2010 r. 
Ogromna liczba multimediów i zdjęć zmusza do skracania informacji, jako gatunku dziennikarskiego, a co za tym idzie - często jej spłycania. Z drugiej strony, Internet daje możliwość umieszczenia większej liczby powiązanych ze sobą artykułów dotyczących jednej lub wielu powiązanych ze sobą kwestii. Mogą one przybierać różną formę - od tekstu, poprzez zdjęcia do materiałów filmowych. W sferze multimedialnej powstała jednolita „platforma” pozwalająca w dowolny sposób łączyć ze sobą różne media, budować złożone przekazy z różnorodnej materii, przy użyciu rozmaitych technik ${ }^{24}$. Inną przyczyną skracania informacji jest wcześniej wspomniana presja czasu, której ulega dziennikarz - materiał podawany szybko, na gorąco, zawiera najważniejszy komunikat z ewentualnym komentarzem dodanym bezpośrednio.

\section{WNIOSKI}

CZY MOŻNA UPRAWIAĆ TRADYCYJNE DZIENNIKARSTWO w warunkach dyktowanych przez multi- i polimedialność przekazu? Raczej nie. Czy można wymagać od mediów tradycyjnych, by - nic ze swoich zasadniczych cech nie zmieniając - zaczęły spełniać funkcje mediów elektronicznych? Także nie. Konwergencja standardów tradycyjnego i nowego dziennikarstwa stanie się możliwa dopiero wtedy, gdy dokona się redefinicji zawodu dziennikarza. Należy sądzić, że wymaga tego sytuacja, jaką wytworzyły „media mieszane”25.

Nieuchronnym zdaje się rozrost sfery, w której lokuje się efekty spontanicznej pracy dotychczasowych odbiorców mediów. W czasach nowego dziennikarstwa jednostki coraz częściej rezygnują z biernego konsumowania napływających informacji oraz odbioru mediów jednokierunkowych ${ }^{26}$. Powstaje jednak pytanie, pod jakimi warunkami dziennikarz zechce ustąpić miejsca odbiorcy. Współtworzenie danego tytułu owocowałoby większym przywiązaniem do jego czytelnika, słuchacza czy widza. Jednak zatarcie granicy pomiędzy producentami i konsumentami materiałów prasowych nasunęłoby wątpliwość, czy w nowych mediach dziennikarz jest jeszcze potrzebny?

Autorzy ostatniego raportu The Project for Excellence in Journalism $(\mathrm{PEJ})^{27}$ przestrzegają, by krytycznych opinii dziennikarzy

${ }^{24}$ Z. Bauer, Dziennikarstwo..., op. cit., s. 286.

${ }^{25}$ Ibidem, s. 291.

${ }^{26}$ L. Olszański, Dziennikarstwo..., op. cit., s. 299.

${ }^{27}$ The changing newsroom: What is being Gained and what is being lost In America's Daily Newspapers?, PEJ Report, http://www.journalism.org/node/11961, 17.10.2010 r. 
o kondycji ich zawodu i mediów, w których pracują, nie traktować jako reprezentatywnych dla całego środowiska. Wielu dziennikarzy twierdzi, że w rozwoju nowych technologii i nowego dziennikarstwa nie widzi zagrożeń ani dla własnej pozycji, ani dla wykonywanej przez nich profesji. Należy jednak mieć na uwadze, że stale rosnącą wiarę w możliwości mediów informacyjnych - wzmacnianych, a nie osłabianych przez nowe technologie - wyraża tylko określona grupa dziennikarzy. Są to te osoby, które nie tylko utrzymały się w zawodzie, lecz potrafią dostosowywać się do stale zmiennych warunków technologiczno-organizacyjnych. Opinii tych, którzy z zawodu odeszli, raport PEJ nie uwzględnia ${ }^{28}$.

Marshall McLuhan twierdzil, że medium jest przekazem ${ }^{29}$. Rozwijając jego tezę, można stwierdzić, że medium wybrane przez nadawcę dyscyplinuje przekaz i wpływa na jego ostateczną formę. Internet bez wątpienia stanowi dziś jedno z najważniejszych mediów. Wpływa też na kształt przekazów dziennikarskich. W efekcie kształtuje się nowe dziennikarstwo. Jakie będą tego skutki - to będzie można stwierdzić dopiero wtedy, gdy nowe dziennikarstwo, podobnie jak i nowe media przestaną być nowe.

\section{SUMMARY}

THE ARTICLE shows the transformation of journalists' and information's functions, basing on the examples coming straight from the internet as it is the cause of all changes. Because of the new media, these functions are far more different today than 20 years ago. Traditional journalism is changing because of the Internet. At the same time, it is also coping with the new reality of presenting news. The question is: Can we call it the new journalism? Journamorfosis in Poland is definitely slower than in other countries. However, it is happening. There is higher control over journalists, even taking away their duties. The author proves that Polish journalism, thanks to the new media, finds itself in a different point than 20 years ago and it is still changing.

${ }^{28}$ Z. Bauer, Dziennikarstwo..., op. cit., s. 290.

${ }^{29}$ M. McLuhanisms, If it works, it's obsolete, http://www.marshallmcluhan.com/ poster.html, 17.10.2010 r. 
Nota O AUTORCE

Małgorzata Mielcarek [mamielcarek@gmail.com] - studentka I roku politologii studiów II stopnia na Wydziale Nauk Politycznych i Dziennikarstwa UAM. Redaktor naczelna „Bardzo Uniwersyteckiego Czasopisma”, współzałożycielka pierwszej wydziałowej telewizji internetowej, współprowadząca programu publicystycznego „Między Nami” produkowanego przez WNPiD UAM, laureatka nagrody Dziennikarskie Koziołki przyznawanej przez Stowarzyszenie Dziennikarzy RP. 